\title{
Carbon Stock Estimates due to Land Cover Changes at Sumber Brantas Sub-Watershed, East Java
}

\author{
Rossyda Priyadarshini ${ }^{1 *}$, Amir Hamzah ${ }^{2}$ and Bakti Wisnu Widjajani ${ }^{1}$ \\ ${ }^{1}$ Department of Agrotechnology, Faculty of Agriculture, University of Pembangunan Nasional Veteran \\ Jawa Timur, Surabaya, Indonesia; ${ }^{2}$ Department of Agroecotechnology, Faculty of Agriculture, \\ University of Tribhuwana Tunggadewi, Malang, Indonesia \\ *Corresponding author: rossyda_p@upnjatim.ac.id
}

\begin{abstract}
Carbon stock is one of the essential types of ecosystem services that are provided by vegetation. Land use has significant effects both directly and indirectly on vegetation cover and strongly influences the carbon stock within the ecosystem. In this study, we have investigated the effect of land cover changes on the carbon stocks at the sub-watershed of Sumber Brantas, Batu city, East Java. This research was conducted at the Junrejo, Batu and Bumiaji districts of Batu city. Land cover classes were determined from satellite imagery. The carbon stock was measured at plot and landscape level using RaCSA. The results showed that forest conversion into plantation forest (pine, Teak, Albizia chinensis, Anthocephalus cadamba) or agricultural land caused losses of the above-ground C-stock of -50 $\mathrm{Mg} \mathrm{ha}^{-1}$, while losses of the underground C-stock were $-20 \mathrm{Mg} \mathrm{ha}^{-1}$. Tree biomass contributes about $60 \%$ of the $\mathrm{C}$-stock on average, while the understorey and necromass contribute $\mathrm{C}$-stock about $2 \%$ and $5 \%$, respectively. Mixed forest has a total C-stock as much as $316.64 \mathrm{Mg} \mathrm{ha}^{-1}$, followed by plantation forest $\left(247.19 \mathrm{Mg} \mathrm{ha}^{-1}\right)$, farmland and scrubland i.e. $51.57 \mathrm{Mg} \mathrm{ha}^{-1}$ and $12 \mathrm{Mg} \mathrm{ha}^{-1}$, respectively. As the consequences of forest conversion into cropland (2008-2012), the Sumber Brantas sub-watershed $(139,447 \mathrm{ha})$ has been lost its C-stock as much as $0.83 \mathrm{Mg} \mathrm{ha}^{-1} \mathrm{yr}^{-1}$, equivalent to $3.04 \mathrm{Mg} \mathrm{CO}_{2} \mathrm{ha}^{-1}$ $\mathrm{yr}^{-1}$. This study showed that $\mathrm{C}$-stock will be maintained by managing and planting woody plant which has high tree biomass.
\end{abstract}

Keywords: carbon stock, forest conversion, land cover, Sumber Brantas sub-watershed

Cite this as: Priyadarshini, R., Hamzah, A., \& Widjajani, B. W. (2019). Carbon Stock Estimates due to Land Cover Changes at Sumber Brantas Sub-Watershed, East Java. Caraka Tani: Journal of Sustainable Agriculture, 34(1), 1-12. doi: http://dx.doi.org/10.20961/carakatani.v34i1.27124

\section{INTRODUCTION}

Forest is an invaluable natural resource because it represents a source of life for humans, either directly or indirectly. The direct source such as a source of timber, cane, vegetable and animal food ingredients and producing gum and drugs. The indirect source such as through watersheds, climate control and the storage of carbon dioxide $\left(\mathrm{CO}_{2}\right)$. Carbon dioxide $\left(\mathrm{CO}_{2}\right)$ is a greenhouse gas that contributes to global warming. The IPCC calculates that there has been an increase in carbon in the past 250 years, from $280 \mathrm{ppm}$ (preindustrial era) to the current $380 \mathrm{ppm}$ (IPCC, 2007). Forest and agricultural land has a vital role in absorbing and slowing the accumulation of $\mathrm{CO}_{2}$ in the atmosphere (Ovando and Caparrós, 2009). Forest has high capability in sequestering carbon. Moreover, forest can trap water from the air and accumulate them as fog deposit (Muchura et al., 2014), store them into their biomass, litter and soil (Bruijnzeel et al., 2011) and provide shade for crops and litter for fertilize the soil (Rhoades, 1996).

\footnotetext{
* Received for publication January 20, 2019

Accepted after corrections January 31, 2019
} 
Land use change is associated with changes in land cover and $\mathrm{C}$-stocks. Land use has a significant direct and indirect effect on vegetation cover and strongly influences the carbon stock by altering the balance between $\mathrm{C}$ sequestration and C losses (Ostle et al., 2009). So, forest conversion will exacerbate the loss of carbon stored in the biomass of plants and release large quantities of $\mathrm{CO}_{2}$ into the atmosphere and diminish soil $\mathrm{C}$ stocks (Salinger, 2007). C-stock on each type of land cover was influenced by many factors, such as above ground biomass (tree biomass, litter input, understorey) and underground biomass (soil C-stock, root and necromass). Depend on the land cover type, the soil C-stocks can also affect the global carbon, by sequestering or releasing the $\mathrm{CO}_{2}$. The soil has an equilibrium potential in carbon storage, depending on the vegetation, climatic conditions and its physicochemical properties. This means that the soil can act as a $\mathrm{C}$ source or sink, depend on the interaction between land cover, cropping system and management practices (Singh and Lal, 2005).

Carbon stock sequestration can be increased by enhancing the soil's capability as a C-sink and by reducing the $\mathrm{CO}_{2}$ emissions. Soil can be a $\mathrm{C}$ sink if there is an improved management practices of marginal lands, such as reforestation, afforestation and deforestation. The most effective means of reducing $\mathrm{CO}_{2}$ emissions to the air is by increasing carbon sequestration in the air through the management of vegetation, especially trees. The sequestration of $\mathrm{CO}_{2}$ and its storage in the biomass of woody trees are an effective method for mitigating the $\mathrm{CO}_{2}$ level in the atmosphere. Increased $\mathrm{CO}_{2}$ sequestration can be achieved by planting and managing trees, through activities that (1) increase the forest area and biomass, (2) increase the tree stock, by increasing the tree growth and population or inhibiting harvesting and (3) establish fast-growing tree plantations. The capability of trees in sequestering carbon was also determined by the tree types; slow growing species with the high tree wood density will sequester much carbon compare with the fast growing species.

Recently, studies on carbon changes have been focused on the how much the $\mathrm{C}$ accumulation in the above-ground biomass and there is still much to be learned about the effect of the land cover change on $\mathrm{C}$ stocks, to understand the change of biomass and soil $\mathrm{C}$ storage due to land cover change. This knowledge will be important in managing and planning the right types of trees that can maintain and increase the C-stock. Carbon stock information will be important in developing viable land cover option for sustaining agriculture and also carbon sequestration. Unfortunately, the availability of information is still insufficient, so further research is still done. An understanding of the impact of land cover change on C stocks is vital in designing the sustainable management of the carbon reservoir. Increasing soil capability as a carbon reservoir is important; both for sustainable agriculture and climate change mitigation. Therefore, this study is essential to (1) estimate the carbon stock in various land cover types in the sub-watershed of Sumber Brantas and (2) identify the primary land cover that can best maintain carbon stocks.

\section{MATERIALS AND METHOD}

The study was carried out within the subwatershed that lies between $115^{0} 17^{\prime} 00^{\prime \prime}$ to $118^{0} 19^{\prime} 00^{\prime \prime}$ East Longitude and $7^{0} 55^{\prime} 30^{\prime \prime}$ to 7057'30" South Latitude. Before the measurement, a quick survey was conducted in the sub-watershed of Sumber Brantas, which cover the three districts of Bumiaji, Junrejo and Batu, Esat Java, Indonesia to identify the existing land cover classes. The basic map used in this study area, the Sumber Brantas sub-watershed is from the Landsat satellite images of 7TM for 2008, 2009 and 2012.

\section{Land cover classification}

The land cover classes in the Sumber Brantas sub-watershed were investigated by determining the control points and checking the validity of land cover as identified through satellite imagery. Then the satellite image data was processed through radiometric correction and geometric correction. Land cover classification on the satellite images was determined using "hierarchical classification," and the land cover classification used the classification system proposed by Anderson et al. (1976). A field ground check was conducted as soon as after completing these processes, to ensure the actual land cover. During the field survey, 15 plots were sampled, including mixed forest, scrubland, rice field, dry-land and garden. 


\section{Carbon stock measurement}

The carbon stock was measured at the plot level and landscape level, using RaCSA (Rapid Carbon Stock Appraisal). The carbon measurements which were performed in this activity consiste of: (a) biomass (living part of the canopy and roots) of the trees and understorey, (b) necromass (dead parts) such as fallen wood, twigs and litter on the soil surface and (c) soil organic matter (SOM) at a depth of 0-30 cm (IPCC, 2007). The ages of the trees, including the forest trees, were obtained through interviews with the farmers and land owners that carried out before selection of the measurement plots.

Measurement was begun with a plot size of $40 \mathrm{~m} \times 5 \mathrm{~m}$ by the ASB protocol (Hairiah and Rahayu, 2007). Plots were available for all components of the land measurement (trees and understorey). Tree biomass (in dry weight) was estimated using an allometric equation by the stem diameter (in $\mathrm{cm}$ ) at $1.3 \mathrm{~m}$ above the ground
$(\mathrm{DBH})$. For all the existing trees on the observation plots, the DBH (diameter at breast height) or diameter at $1.3 \mathrm{~m}$ from the ground was measured. The DBH data obtained were used to estimate the basal area and tree biomass using allometric equations corresponding to the pattern of branches and corrected by the density of the wood. Table 1 listed the allometric equations used in this study, which depended on the vegetation type. For wood density, values from various works in the literature were used. Necromass sampling, litter and soil measurements were carried out on a $200 \mathrm{~m}^{2}$ plot with working procedures following those of RaCSA (Hairiah and Rahayu, 2007). The allometric equation for necromass (dead trees) and non branching trees are the same, cause for both of the biomass category the C-stock was estimated only for the parts of the standing tree. Total $\mathrm{C}$ content of carbon biomass was estimated using following equation:

Table 1. Allometric equations for calculating carbon stock

\begin{tabular}{|c|c|c|}
\hline Biomass category & Allometric equation & Source \\
\hline Branching trees & $\mathrm{B}=0.11 \rho \mathrm{D}^{2.62}$ & Ketterings et al., 2001 \\
\hline Non-branching trees & $\mathrm{B}=(\pi / 40) \rho \mathrm{H} \mathrm{D}^{2}$ & Hairiah et al., 2011 \\
\hline Necromass (dead trees) & $\mathrm{B}=(\pi / 40) \rho \mathrm{H} \mathrm{D}^{2}$ & Hairiah et al., 2011 \\
\hline Coffee (pruned) & $\mathrm{B}=0.281 \mathrm{D}^{2.06}$ & Arifin, 2001; van Noordwijk et al., 2002 \\
\hline Banana & $\mathrm{B}=0.030 \mathrm{D}^{2.13}$ & Arifin, 2001; van Noordwijk et al., 2002 \\
\hline Paraserianthes falcataria & $\mathrm{B}=0.0272 \mathrm{D}^{2.531}$ & van Noordwijk et al., 2002 \\
\hline
\end{tabular}

Leaf litter production was estimated by collecting the litter at each site. Litter samples were separated into leaves and miscellaneous (wood, fruits, flowers) before drying at $70{ }^{\circ} \mathrm{C}$ for $72 \mathrm{~h}$. At each site, the soil was sampled in three randomly located plots separated by at least $30 \mathrm{~m}$. In each plot, three soil cores were collected at a depth of $0-10 \mathrm{~cm}$ and $10-20 \mathrm{~cm}$.

\section{RESULTS AND DISCUSSION}

\section{Land cover system}

The Sumber Brantas sub-watershed covers an area of 139.45 ha, including the three districts of Junrejo, Batu and Bumiaji. Of the total area, $34.89 \%$ is managed by farmers (garden, dryland and upland rice). Generally, five types of land cover systems are found, i.e. forest, scrubland, rice field, dryland and garden (Figure 1). The forest comprises secondary forest and forest plantation. The secondary forest is a degraded forest which is dominated by various ages of the plant, scrubland and understorey. Nevertheless, the forest plantation is an industrial planted forest and is managed either by the state or by land owners and by the community. The plantation forest comprises pine, teak, Albizia chinensis, Toona sinensis and Anthocephalus cadamba.

The agricultural land area of perennial plants, either dryland, garden, or upland rice are quite large and dominated by tomatoes, chicory, celery and maize. The maizeis are rotated with chili and planted in multiple cropping systems with the other perennial plants. Fertilizer is applied every season, using either chemical fertilizer or cow manure.

Conversion of natural forest into cropland was mostly happen between 2008s and 2009s (Figure 1). Significant increasing of cropland area was assumed as deforestation. Deforestation from 
forest to garden, dryland and upland rice was $117.12 \%, 97.71 \%, 38.88 \%$, respectively. While, the establishment of plantation area was also occurred which increased significantly as much as $43 \%$ in this time scale.
Changes of land cover, particularly deforestation was the main driver in increasing carbon dioxide emission (Ciais et al., 2013). According to Houghton et al. (2012), land cover changes resulted in almost $12.51 \%$ of the anthropogenic $\mathrm{CO}_{2}$ emissions.

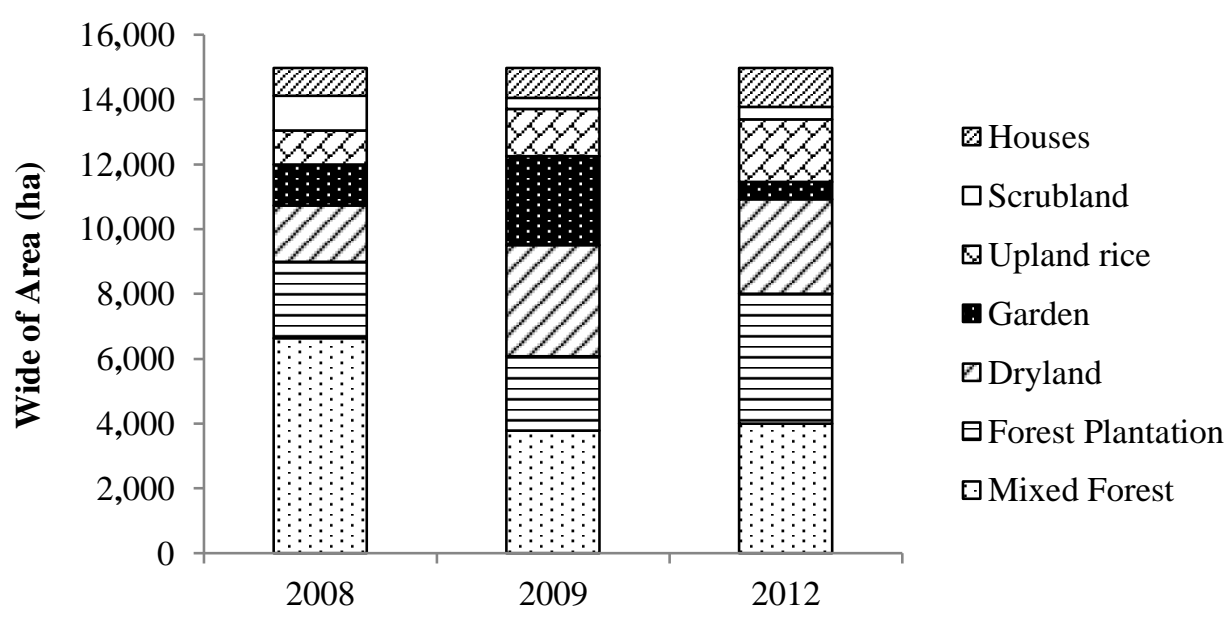

(a)

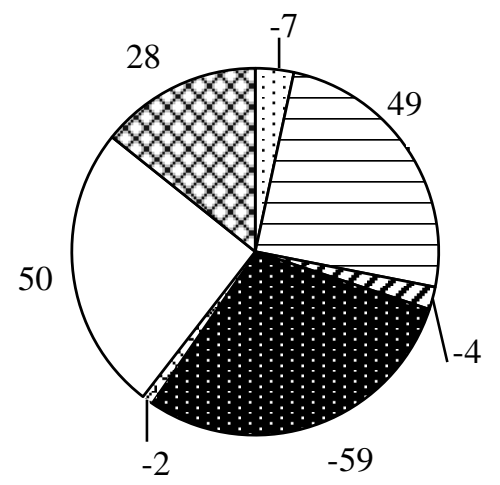

๑ Mixed Forest

曰Forest Plantation

$\square$ Dryland

Garden

$\lambda$ Upland rice

$\square$ Scrubland

$\checkmark$ Houses

(b)

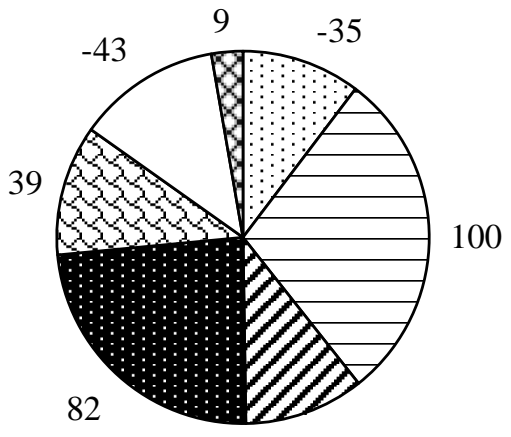

36

\author{
$\square$ Mixed Forest \\ $\boxminus$ Forest Plantation \\ $\square$ Dryland \\ - Garden \\ Q Upland rice \\ $\square$ Scrubland \\ 囚 Houses
}

(c)

Figure 1. a) Land cover changes based on satellite images of 2008, 2009 and 2012, (b) Percentage of land cover changes on 2009 and (c) Percentage of land cover changes on 2012

(Note: negative (-) sign indicates a decrease in area extent) 


\section{Carbon Stock}

Soil organic carbon (SOC) content under different land cover types

Changes in land cover affect significantly on soil organic C. Our study found that there was a high variation of soil C-stock between land cover types. A very high soil C-stock was noted in land covered with woody trees, such as mixed forest (30 $\mathrm{Mg} \mathrm{ha}^{-1}$ ) and plantation forest types $(24 \mathrm{Mg}$ ha $\left.^{-1}\right)$, compared with in other types of land cover (Figure 2). It seems that agricultural activities were the main factors in the declining soil C-stock during the land conversion.

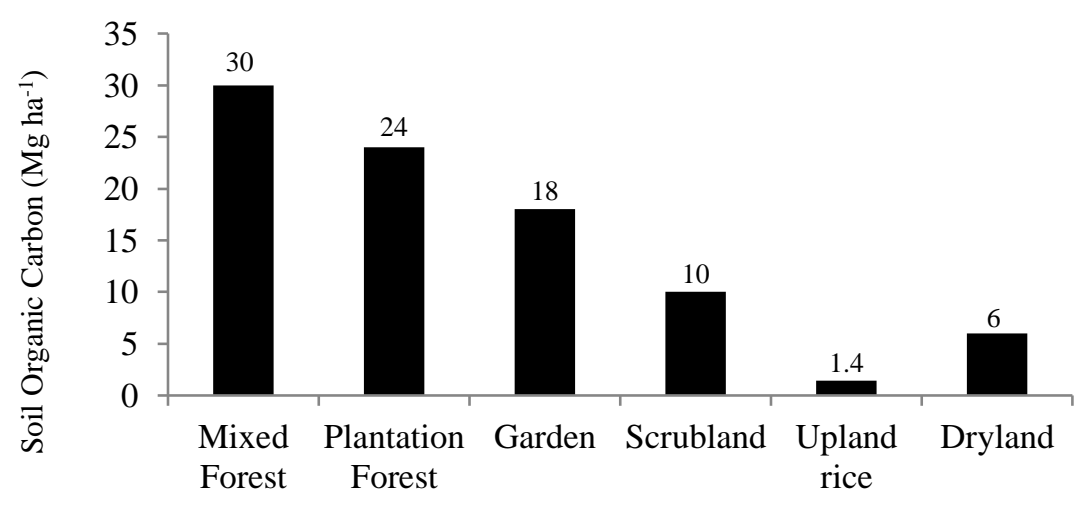

Figure 2. Soil organic carbon content on various land cover types

The soil C-stock differed between land cover types. There was a positive impact from tree species diversity on soil organic carbon (SOC) (Chen, 2006). Soil C is susceptible to be changed and it can be increased or decreased by the change of land cover, which can alter the soil $\mathrm{C}$ inflows and outflows, thus altering the SOC stocks (Deng et al., 2016). As shown in Figure 2, the change of mixed forest to other land cover reduced the soil C-stock, where the most significant decrease in soil C-stock occurred with the upland rice and the least was in the plantation forest. According to Deng et al. (2016), landcover conversion will

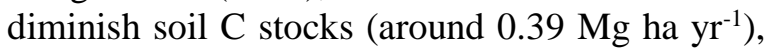
depends on the landcover types. Changes of farmland into grassland or forest into grassland will be increased the soil $\mathrm{C}$ stocks, on the contrary soil $\mathrm{C}$ stocks will diminish if the land cover changes into farmland (0.84-1.74 Mg ha $\left.\mathrm{yr}^{-1}\right)$.

The conversion of forest into plantation and even into agricultural land have reduced the input of $\mathrm{C}$ into the soil compared with the previous land cover and this, combined with the accelerated decomposition of soil organic matter due to disturbance, led to the net loss of SOC (Richards et al., 2007; Haghdoost et al., 2013). Forest conversion to cropland decreases the soil organic carbon because organic carbon is continuously harvested and removed from the system in this type of land cover and is thus not recycled as litter as in the forest system (Rittl et al., 2017), which leads to a decrease in soil carbon. Under cropland, the $\mathrm{C}$ input is low and the $\mathrm{C}$ output due to degradation is high. Increasing of erosion frequency within the first years also declined the soil C stock after forest conversion (Lewis et al., 2016). Amundson et al. (2015) also reported that there were large declines of soil organic carbon on the conversion of natural habitats such as forest into agricultural land. Undisturb sites, such as forest will have higher soil organic carbon compared with the disturb sites at the edge of the forest (Muhati et al., 2018).

Some other reasons such as local climate, specific site conditions, parents rock and vegetation type could also influence the spatial variability of soil $\mathrm{C}$ stock. The patterns of accumulation and loss of $\mathrm{C}$ vary according to location, soil type, tree species and plantation management system. The soil $\mathrm{C}$ content is also influenced by the litter input in each of the land cover types. The research shows that the litter input in the mixed forest is the highest $(8.97 \mathrm{Mg}$ $\left.\mathrm{ha}^{-1} \mathrm{yr}^{-1}\right)$, followed by plantation forest $(6.04 \mathrm{Mg}$ $\mathrm{ha}^{-1} \mathrm{yr}^{-1}$ ).

The differences of $\mathrm{C}$ content among the land covers could be due to the differences in the plant material, which cause differences of the $\mathrm{C}$ input. 
The conversion of mixed forest to agricultural land is usually followed by a decrease in SOC stocks (Guo and Gifford, 2002). The conversion of mixed forest to agricultural land reduces SOC, although this was not significant statistically. According to Tomlinso (2006), the soil carbon varies with land cover; a soil with semi-natural vegetation cover (trees) has a higher soil $\mathrm{C}$ than soil with grass cover. The tree age, which is shown by their basal area also influences the SOC. According to Arevalo et al. (2009), soil C loss in young poplar plantations was followed by SOC stock that increased with the plantation age, so increasing the age of plantations would increase SOC.

\section{Total carbon biomass}

The C-stock in each land use system indicates the carbon dynamics. The C-stock storage in biomass varies with the different types of land cover. These differences are influenced by the differences between species, density and the tree age. Even though the mixed forest at Sumber Brantas sub-watershed has been degraded, with the total C-stock about $202.76 \mathrm{Mg} \mathrm{ha}^{-1}$ in the tree biomass, that still seems high (Figure 3). According to Pellikka et al. (2018) woody vegetation constitute almost half of the above ground carbon stocks in Africa.

The biomass $\mathrm{C}$ storage was highest in the mixed forest followed by the plantation forest. This study showed that $\mathrm{C}$ biomass storage differed for different species. Tree plantation which is dominated with pine, teak, Albizia chinensis and Anthocephalus cadamba has more $\mathrm{C}$ in its biomass $\left(155.63 \mathrm{Mg} \mathrm{ha}^{-1}\right)$. This results was similar with Omoro et al. (2013) which reported that for exotic forest that is dominated by cypress, eucalyptus and pine, the total above ground C-stock was 158; 221 and $195 \mathrm{Mg} \mathrm{C} \mathrm{ha}{ }^{-1}$ respectively. Primary forest has higher C-stock compared with agricultural land. Changes of forest into agricultural land is caused loss of C-stock.

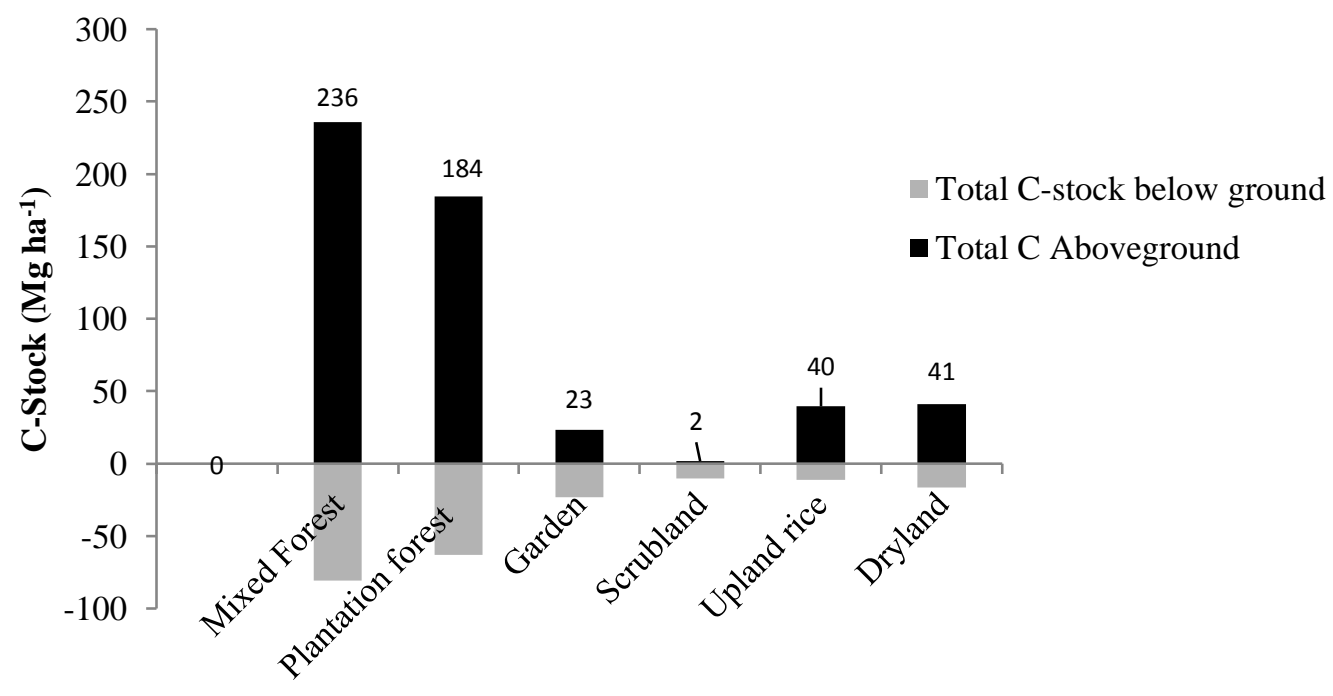

Figure 3. Total C-stock on aboveground and belowground on various landuse types

This result coincides with Lasco and Pulhin (2009), which showed that tree plantation with the dipterocarp natural forest containing $119.43 \mathrm{Mg}$ $\mathrm{ha}^{-1}$. The C-stock storage in biomass depends on species growth, environmental conditions (such as weather and soil), site management (such as pruning and thinning) and other factors (Haghdoost et al., 2013). Each species in each site condition will show different rates of $\mathrm{C}$ accumulation in its biomass.

\section{Carbon stock components}

The total C-stock (vegetation, litter, biomass and SOC) is significantly affected by land cover changes. The total amount of $\mathrm{C}$-stock in each land cover system was determined from different carbon pools, such as tree biomass, understorey, necromass (dead parts of the plant, such as leaves, branches and tree trunks) and the soil carbon content. Measurement of the C-stock of living and dead parts of plants from each land cover system contributes highest total C-stock $(60 \%$ on 
average) (Figure 4). The understorey and necromass contribute only about $2 \%$ and $5 \%$ of the total C-stock, especially for agricultural land (garden, dryland, upland rice). This is due to weed cultivation by farmers.

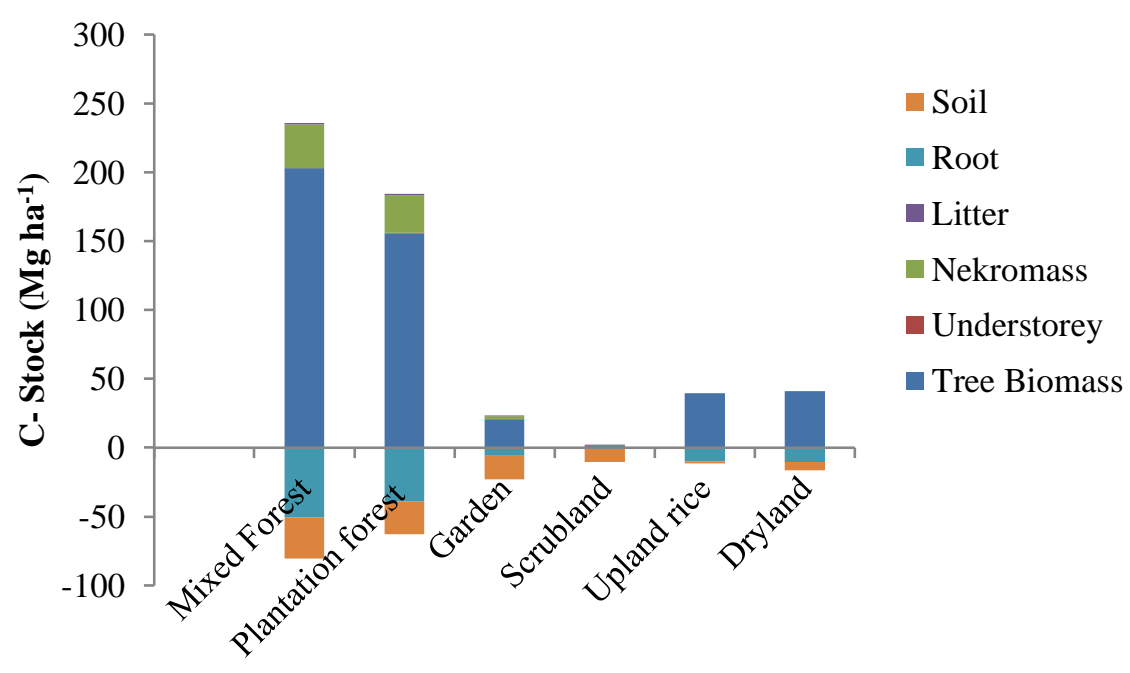

Figure 4. Total $\mathrm{C}$ stock which is represented as sum of $\mathrm{C}$ stock of each component of landuse system at sub-watersehed Sumber Brantas

The mixed forest has the highest $\mathrm{C}$-stock of tree biomass, followed by the plantation forest and agricultural land. The differences of $\mathrm{C}$ storage in each land cover system are influenced by the tree species diversity. Mixed forest has greater diversity $\left(H^{\prime}=1.80\right)$, while the other land cover types $\left(\mathrm{H}^{\prime}=0.85-1.14\right)$ have less tree diversity. Generally, the carbon concentration varies among species and within trees and also between fastand slow-growing species.

Plants can absorb atmospheric $\mathrm{CO}_{2}$ during photosynthesis and store it in standing vegetation or biomass. The tree stands characteristics (tree height and age) and stand structural diversity indices (Wang et al., 2011) affect a tree's ability to store $\mathrm{CO}_{2}$. Generally, the $\mathrm{DBH}$, height, volume and structural diversity indices increase as the age of the stands increases, but not with the tree species diversity. Nevertheless, all of the structural diversity indices have a positive impact on the above-ground C-stocks. Therefore, small changes in this component will result in substantial changes to the carbon stored in plant biomass.

Tree size diversity has a substantial effect on above-ground carbon stocks. The complexity of the tree size and structure leads to a high resource use efficiency due to the efficiency of light infiltration and hence supports better resource utilization by trees. The trees in plantation forest are dominated with the old trees with diameters of $30-50 \mathrm{~cm}$. Trees with a diameter of more than $30 \mathrm{~cm}$ make a significant contribution to the carbon stock (Hairiah and Murdiyarso, 2007) and contribute almost $80 \%$ of the total carbon stock. The higher is the tree density and tree diameter, the greater is the stored carbon. Trees with a high density will grow more slowly. On the other hand, the faster growth, the more carbon is stored, but the sooner that carbon will be lost due to being harvested earlier.

The process of carbon accumulation in plants is known as $\mathrm{C}$-sequestration. $\mathrm{C}$ stored in biomass indicates the amount of $\mathrm{CO}_{2}$ that is absorbed by plants, while emission is the process of releasing $\mathrm{CO}_{2}$ into the atmosphere. Land cover changes from mixed forest to agricultural land will increase carbon emission to the atmosphere, because of logging, harvesting and transporting trees to other areas.

The mixed forest has the lowest content of Cstock in the understorey pool. This is due to the thick layer of litter that constrains the understorey growth. However, the litter C-stock in mixed forest is estimated to be $1.42 \mathrm{Mg} \mathrm{ha}^{-1}$. After changing the land cover to plantation or agriculture, the litter storage is depleted 0.12- 
$0.73 \mathrm{Mg} \mathrm{ha}{ }^{-1}$. We assume because of the differences of species characteristics.

The root contribution to the carbon stock did not differ significantly between land cover (around 10-19\%). Root biomass development depends on the tree age and species. It is also related to the stand architecture, composition and the tree's biophysical traits. So, the significant similarities of the root contribution between two types of land cover (mixed forest and plantation forest) compared with other land cover (agricultural land) could be associated with these characteristics.

\section{C-stock estimates}

Land cover changes seems to be a driving force for carbon stocks changes; analyzing of land cover could be done from land use changes. Fragmentation of vegetation which caused land cover changes, especially changes into built areas, such as houses (Muriuki et al., 2011). In this study site, the areal land cover systems have been changed, which took place for many reasons. The conversion of natural forest to cropland mostly happened between 2008 and 2009 (Figure 1). The significant increase of the cropland area is assumed to indicate deforestation, which represents changes from forest to other land cover, including garden (117.12\%), dryland (97.71\%) and upland rice $(38.89 \%)$. Meanwhile, the establishment of plantation areas also occurred, increasing significantly (43\%) in this timescale.

Table 2. Landcover changes at Sumber Brantas sub-watershed (2008-2012)

\begin{tabular}{lrrr}
\hline Landuse/ & \multicolumn{3}{c}{ Year (ha) } \\
\cline { 2 - 4 } Landcover & 2008 & 2009 & \multicolumn{1}{c}{2012} \\
\hline Mixed & & & \\
forest & $6,645.0$ & $3,789.9$ & $4,000.0$ \\
Plantation & $2,345.0$ & $2,285.0$ & $4,008.0$ \\
forest & & & \\
Dryland & $1,741.0$ & $3,442.2$ & $2,921.0$ \\
Garden & $1,261.0$ & $2,737.9$ & 520.0 \\
Upland rice & $1,047.0$ & $1,454.0$ & $1,929.0$ \\
Scrubland & $1,088.0$ & 336.5 & 406.0 \\
Housing & 848.0 & 927.3 & $1,191.0$ \\
\hline Total & $14,975.0$ & $14,972.8$ & $14,975.0$ \\
\hline
\end{tabular}

C-stock changes at the Sumber Brantas subwatershed were estimated by integrating the data of land cover changes with the data on the aboveground C-stock for every land cover system. Land cover identification at the Sumber Brantas subwatershed in 2009 and 2012 showed the changes of land cover area in mixed forest, plantation forest, garden, dryland, upland rice, scrubland and housing.

There was a decrease from 2008 to 2009 of the land covered by mixed forest $(2,855.10 \mathrm{ha})$ and scrubland (160.70 ha). On the other hand, there was an increase in agricultural land by 3,585.13 ha and housing by 511.50 ha. Land cover changes from forest to agricultural land and housing will influence the carbon stored above ground. Solomon et al. (2018) stated that land cover change significantly affect the carbon stock through the above ground biomass and soil organic carbon. On the contrary, changes from non forest into forest ecosystem will increase the carbon sequestration potential.

Field measurements at various land cover systems in the Sumber Brantas sub-watershed showed C-stock as much as $316.64 \mathrm{Mg} \mathrm{ha}^{-1}$ in mixed forest, followed by plantation forest (247.19 $\left.\mathrm{Mg} \mathrm{ha}^{-1}\right)$. However, agricultural land has the lowest C-stock with an average of $51.57 \mathrm{Mg}$ $\mathrm{ha}^{-1}$. Scrubland was estimated to store as much as 12.00 $\mathrm{Mg} \mathrm{ha}^{-1}$ of carbon. Mixed forest conversion to plantation forest (pine, teak, Albizia chinensis, Anthocephalus cadamba) or crops caused C-stock losses above ground of about $-50 \mathrm{Mg} \mathrm{ha}^{-1}$, while the below-ground $\mathrm{C}$ losses were $-20 \mathrm{Mg} \mathrm{ha}^{-1}$.

In period of 2009 and 2012, land cover changes in the mixed forest and plantation forest area increase 210.10 and $1,723.00$ ha, respectively. The enhancement of forest area was the result of dryland conversion (521.20 ha) and the garden area $(2,217.90 \mathrm{ha})$.

The extrapolation of carbon stocks from plot level to landscape level was done by multiplying the data of the coverage areas in 2008, 2009 and 2012 (Figure 4) by time-averaged $\mathrm{C}$ for each land cover system. The results showed that the C-stock at the Sumber Brantas sub-watershed was 1.84 Mton (2008), 1.60 Mton (2009) and 1.69 Mton (2012). This data showed that there was a reduction of C-stock from 2008 to 2012, even though from 2009 to 2012 the decrease was not significant. 


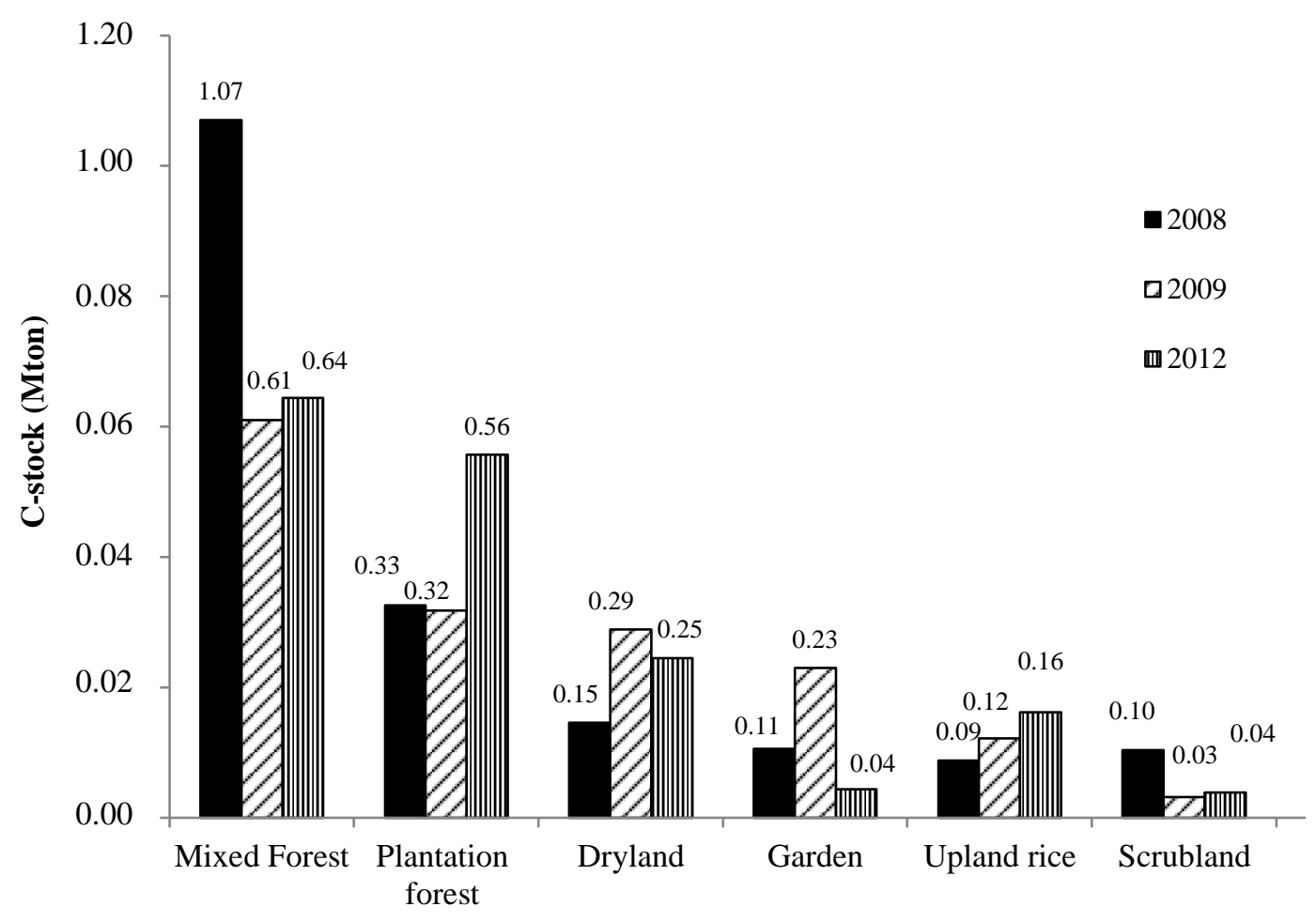

Land cover types

Figure 5. Total C stock on various land cover system at sub-watershed Sumber Brantas

About $58 \% \mathrm{C}$-stock was stored in the mixed forest (1.07 Mton), which was higher than in plantation forest (0.33 Mton), garden (0.11 Mton) and dryland (0.15 Mton). Comparing the C-stock in 2009 and 2012, the C-stock tends to decline because of forest conversion to dryland, garden and upland rice. These land cover types cannot store large amounts of $\mathrm{C}$ over an extended period.

The carbon deposit in the mixed forest and scrubland decreased by $45,967.10 \mathrm{Mg}$ and $71,392.50 \mathrm{Mg}$, respectively. A dramatic increase of the dryland and garden areas in 2009 caused the increase of C-stock by $50 \%$. However, although the stored carbon was increased, it was stored only for a short time so that carbon emission would occur rapidly. In the mixed forest, it was estimated that there would be a carbon loss of about $46 \%$ of the total C-stock in $2008(845.46 \mathrm{Mg})$. All conversions of natural vegetation to agricultural land-use systems in the different biomes have resulted in significant losses of soil carbon stocks (Coutinho et al., 2015). On the contrary, the carbon stored in the agricultural land would be increased by (184.63 $\mathrm{Mg}$ on average). Our research results were coincide with Gnanavelrajah et al. (2008) which is found that agricultural land- uses estimates contribute total C-stocks as much as $20.5 \mathrm{Tg}$ of which 41.49 percent was belong to biomass and 58.51 was soil $\mathrm{C}$.

As the consequences of forest conversion into cropland in the 2008-2012 period (4 years), shown in Table 2, all areas of the Sumber Brantas subwatershed $(139,447$ ha) have already lost C-stock as much as $23,8252.85 \mathrm{Mg} \mathrm{yr}^{-1}$, or $0.31 \mathrm{Mg} \mathrm{C}$ $\begin{array}{llllll}\text { ha }^{-1} & \mathrm{yr}^{-1} & \text { (equivalent to } 3.04 & \mathrm{Mg} & \mathrm{CO}_{2}\end{array}$ $\left.\mathrm{ha}^{-1} \mathrm{yr}^{-1}\right)$. The carbon stored in the mixed forest has diminished $\mathrm{C}$ by $4,59671.1 \mathrm{Mg}$ each year, because of the logging and transporting of tree biomass to other areas. However, at the same time, there was an increase of stored carbon in cropland by $30,1150.75 \mathrm{Mg}$. Carbon sequester in croplands in Kenya also shown the same results, increased from $7 \%$ to $11 \%$ (Pellikka et al., 2018) and $2 \%$ increased carbon stock on agricultural land (Zomer et al., 2016).

Table 2 showed the increasing of forest plantation area on 2008-2009 and 2009-2012. This change of land cover was caused by changing of farmers choices from agriculture into plantation forest. Farmers will get more income from trees than from crops. Our study results showed that trees with $\mathrm{D}>10 \mathrm{~cm}$ has significant capability in 
sequestering carbon. It means that minimizing landcover change into agricultural land must be attempted in conserving carbon stocks. But to meet the agricultural production needs, it is need to link the natural habitat such as forest and agricultural production. One of the model that can be used was community based forest.

\section{CONCLUSIONS}

Land cover change affects significantly total C storage in an ecosystem. Changing the land cover from forest either to plantation forest or agricultural land will reduce the total carbon stock. The carbon stock in various land cover types in the sub-watershed of Sumber Brantas respectively were $316.64 \mathrm{Mg} \mathrm{C}$ ha $^{-1}$ (mixed forest); $247.19 \mathrm{Mg} \mathrm{C} \mathrm{ha}^{-1}$ (plantation forest); $57.46 \mathrm{Mg} \mathrm{C} \mathrm{ha}{ }^{-1}$ (dryland); $50.85 \mathrm{Mg} \mathrm{C}^{-1}$ (upland rice); $46.40 \mathrm{Mg} \mathrm{C} \mathrm{ha}^{-1}$ (garden) and 12.00 $\mathrm{Mg} \mathrm{C} \mathrm{ha-1} \mathrm{(shrubland).}$

In all land cover types, large amounts of $\mathrm{C}$ were stored in the above-ground biomass. It means that the best way in maintaining carbon stock in each of landcover types was increasing the existence of trees. It is important to maintain trees in long term. Therefore it is recommended to improve the land management to increase the tree biomass. It is also recommended to apply agroforestry systems to increase the biomass on agricultural land, thereby also increasing the total ecosystem C-stock.

\section{ACKNOWLEDGEMENT}

Authors thank the SEAMEO-BIOTROP which is fund this research from BIOTROP-Grant Research scheme, which was facilitated by University of Pembangunan Nasional Veteran Jawa Timur.

\section{REFERENCES}

Amundson, R., Berhe, A. A., Hopmans, J. W., Olson, C., Sztein, A. E., \& Sparks, D. L. (2015). Soil and human security in the $21 \mathrm{st}$ century. Science, 348(6235), 2500-2505. https://doi.org/10.1126/science.1261071

Anderson, J. R., Hardy, E. E., Roach, J. T., \& Witmer, R. E. (1976). A land use land cover classification system for use with remote sensing data: a revision of the land use classification system. Professional Paper. https://doi.org/10.3133/PP964
Arevalo, C. B. M., Bhatti, J. S., Chang, S. X., \& Sidders, D. (2009). Ecosystem carbon stocks and distribution under different land-uses in north central Alberta, Canada. Forest Ecology and Management, 257(8), 1776-1785. https://doi.org/10.1016/j.foreco.2009.01.034

Arifin, J. (2001). Estimasi Cadangan Karbon pada Berbagai Sistem Penggunaan Lahan di Kecamatan Ngantang, Malang. Universitas Brawijaya.

Bruijnzeel, L. A., Scatena, F. N., \& Hamilton, L. S. (2011). Tropical montane cloud forests: Science for conservation and management. Tropical Montane Cloud Forests: Science for Conservation and Management. Cambridge: Cambridge University Press. https://doi.org/ 10.1017/CBO9780511778384

Chen, X. (2006). Tree Diversity, Carbon Storage and Soil Nutrient in an Old-Growth Forest at Changbai Mountain, Northeast China. Communications in Soil Science and Plant Analysis, 37(3-4), 363-375. https://doi.org/ $10.1080 / 00103620500440210$

Ciais, P., Sabine, C., Bala, G., Bopp, L., Brovkin, V., Canadell, J., ... Thornton, P. (2013). Carbon and Other Biogeochemical Cycles. In: Cli-mate Change 2013: The Physical Science Basis. Contribution of Working Group I to the Fifth Assessment Report of the Intergovernmental Panel on Climate Change [Stocker, T.F., D. Qin, G.-K. Plattner, M. Tignor. Cambridge, United Kingdom and New York, NY, USA. Retrieved from https://www.ipcc.ch/site/assets/uploads/2018/ 02/WG1AR5_Chapter06_FINAL.pdf

Coutinho, H. L. C., Noellemeyer, E., Balieiro, F. de C., Piñeiro, G., Fidalgo, E. C. C., Martius, C., \& Silva, C. F. da. (2015). Impacts of landuse change on carbon stocks and dynamics in central-southern South American biomes: Cerrado, Atlantic Forest and Southern Grasslands. In Soil carbon: science, management and policy for multiple benefits (pp. 243-264). Wallingford: CABI. https://doi.org/10.1079/9781780645322.0243

Deng, L., Zhu, G. yu, Tang, Z. sheng, \& Shangguan, Z. ping. (2016). Global patterns of the effects of land-use changes on soil carbon stocks. Global Ecology and Conservation, 5, 127-138. 
https://doi.org/10.1016/j.gecco.2015.12.004

Gnanavelrajah, N., Shrestha, R. P., Schmidt-Vogt, D., \& Samarakoon, L. (2008). Carbon stock assessment and soil carbon management in agricultural land-uses in Thailand. Land Degradation and Development, 19(3), 242-256. https://doi.org/10.1002/ldr.838

Guo, L. B., \& Gifford, R. M. (2002). Soil carbon stocks and land use change: A meta analysis. Global Change Biology, 8(4), 345-360. https://doi.org/10.1046/j.1354-

1013.2002.00486.x

Haghdoost, N., Akbarinia, M., \& Hosseini, S. M. (2013). Land-use change and carbon stocks: A case study, Noor County, Iran. Journal of Forestry Research, 24(3), 461-469. https://doi.org/10.1007/s11676-013-0340-2

Hairiah, K., Dewi, S., Agus, F., van Noordwijk, M., \& Rahayu, S. (2011). Measuring Carbon Stocks Across Land Use Systems: A Manual. Bogor: World Agroforestry Centre (ICRAF), SEA Regional Office. Retrieved from http://www.worldagroforestry.org/sea/Publica tions/files/manual/MN0050-11/MN0050-111.pdf

Hairiah, K., \& Murdiyarso, D. (2007). Alih Guna Lahan dan Neraca Karbon Terestrial. Bogor: World Agroforestry Centre (ICRAF) Southeast Asia Regional Office. Retrieved from https://dokumen.tips/documents/alihguna-lahan-dan-neraca-karbon-terestrial.html

Hairiah, K., \& Rahayu, S. (2007). Pengukuran 'Karbon Tersimpan' di berbagai Macam Penggunaan Lahan. Bogor: Bogor: World Agroforestry Centre-ICRAF, Southeast Asia Regional Office. Retrieved from http://www.worldagroforestry.org/sea/Publica tions/files/manual/MN0035-07/MN0035-071.pdf

Houghton, R. A., House, J. I., Pongratz, J., van der Werf, G. R., DeFries, R. S., Hansen, M. C., ... Ramankutty, N. (2012). Carbon emissions from land use and land-cover change. Biogeosciences, 9(12), 5125-5142. https:// doi.org/10.5194/bg-9-5125-2012

IPCC. (2007). Summary for Policymakers. In: Climate Change 2007: Mitigation. Contribution of Working Group III to the Fourth Assessment Report of the
Intergovernmental Panel on Climate Change [B. Metz, O.R. Davidson, P.R. Bosch, R. Dave, L.A. Meyer (eds)]. Cambridge, United Kingdom and New York, NY, USA. Retrieved from https://www.ipcc.ch/site/assets/uploads/ 2018/03/ar4_wg3_full_report-1.pdf

Ketterings, Q. M., Coe, R., Van Noordwijk, M., Ambagau', Y., \& Palm, C. A. (2001). Reducing uncertainty in the use of allometric biomass equations for predicting aboveground tree biomass in mixed secondary forests. Forest Ecology and Management, 146(1-3), 199-209. https://doi.org/10.1016/ S0378-1127(00)00460-6

Lasco, R. D., \& Pulhin, F. B. (2009). Carbon Budgets of Forest Ecosystems in the Philippines. Journal of Environmental Science and Management, 12(1), 1-13. Retrieved from https://www.researchgate.net/publication/265 740827_Carbon_Budgets_of_Forest_Ecosyst ems_in_the_Philippines

Lewis, T., Smith, T. E., Hogg, B., Swift, S., Verstraten, L., Bryant, P., ... Dalal, R. C. (2016). Conversion of sub-tropical native vegetation to introduced conifer forest: Impacts on below-ground and above-ground carbon pools. Forest Ecology and Management, 370, 65-75. https://doi.org/ 10.1016/j.foreco.2016.03.058

Muchura, Henry, M., Min, S., Chua, Mworia, John, K., \& Gichuki, N. N. (2014). Role of Bryophytes And Tree Canopy In Mist Trapping In Mt. Marsabit Forest. Journal of Environment and Earth Science, 4(21), 128138. Retrieved from https://www.iiste.org/ Journals/index.php/JEES/article/view/17441

Muhati, G. L., Olago, D., \& Olaka, L. (2018). Quantification of carbon stocks in Mount Marsabit Forest Reserve, a sub-humid montane forest in northern Kenya under anthropogenic disturbance. Global Ecology and Conservation, 14, e00383. https://doi.org/ 10.1016/J.GECCO.2018.E00383

Muriuki, G., Seabrook, L., McAlpine, C., Jacobson, C., Price, B., \& Baxter, G. (2011). Land cover change under unplanned human settlements: A study of the Chyulu Hills squatters, Kenya. Landscape and Urban Planning, 99(2), 154-165. https://doi.org/ 10.1016/j.landurbplan.2010.10.002 
Omoro, L. M. A., Starr, M., \& Pellikka, P. K. E. (2013). Tree biomass and soil carbon stocks in indigenous forests in comparison to plantations of exotic species in the Taita Hills of Kenya. Silva Fennica, 47(2), 1-18. https://doi.org/Http://dx.doi.org/10.14214/sf.9 35

Ostle, N. J., Levy, P. E., Evans, C. D., \& Smith, P. (2009). UK land use and soil carbon sequestration. Land Use Policy, 26, S274-S283. https://doi.org/10.1016/ J.LANDUSEPOL.2009.08.006

Ovando, P., \& Caparrós, A. (2009). Land use and carbon mitigation in Europe: A survey of the potentials of different alternatives. Energy Policy, 37(3), 992-1003. https://doi.org/ 10.1016/J.ENPOL.2008.10.041

Pellikka, P. K. E., Heikinheimo, V., Hietanen, J., Schäfer, E., Siljander, M., \& Heiskanen, J. (2018). Impact of land cover change on aboveground carbon stocks in Afromontane landscape in Kenya. Applied Geography, 94, 178-189. https://doi.org/10.1016/J.APGEOG. 2018.03.017

Rhoades, C. C. (1996). Single-tree influences on soil properties in agroforestry: lessons from natural forest and savanna ecosystems. Agroforestry Systems, 35(1), 71-94. https://doi.org/10.1007/BF02345330

Richards, A. E., Dalal, R. C., \& Schmidt, S. (2007). Soil carbon turnover and sequestration in native subtropical tree plantations. Soil Biology and Biochemistry, 39(8), 2078-2090. https://doi.org/10.1016/j.soilbio.2007.03.012

Rittl, T. F., Oliveira, D., \& Cerri, C. E. P. (2017). Soil carbon stock changes under different land uses in the Amazon. Geoderma Regional, 10, 138-143. https://doi.org/10.1016/J.GEODRS. 2017.07.004

Salinger, M. J. (2007). Agriculture's influence on climate during the Holocene. Agricultural and Forest Meteorology, 142(2-4), 96-102. https://doi.org/10.1016/J.AGRFORMET.2006

\section{.03 .024}

Singh, B. R., \& Lal, R. (2005). The potential of soil carbon sequestration through improved management practices in Norway. Environment, Development and Sustainability, 7(1), 161-184. https://doi.org/10.1007/s10668 $-003-6372-6$

Solomon, N., Pabi, O., Annang, T., Asante, I. K., $\&$ Birhane, E. (2018). The effects of land cover change on carbon stock dynamics in a dry Afromontane forest in northern Ethiopia. Carbon Balance and Management, 13(1), 14. https://doi.org/10.1186/s13021-018-0103-7

Tomlinso, R. W. (2006). CLIMATE CHANGELand Use, Land-Use Change and Carbon Stocks (2000-LS-5.1.2a-M1)Synthesis Report. Johnstown Castle. Retrieved from https://www.epa.ie/pubs/reports/research/clim ate/EPA_climate_change_land_use_ERTDI4 7.pdf

van Noordwijk, M., Rahayu, S., Hairiah, K., Wulan, Y. C., Farida, A., \& Verbist, B. (2002). Carbon stock assessment for a forest-to-coffee conversion landscape in Sumber-Jaya (Lampung, Indonesia): from allometric equations to land use change analysis. SCIENCE IN CHINA (Series C), 45, 75-86. Retrieved from http://www.globalcarbon project.org/global/pdf/landuse_Canadell_Zho u_Noble2003/Noordwijk_yc0075.pdf

Wang, W., Lei, X., Ma, Z., Kneeshaw, D. D., \& Peng, C. (2011). Positive Relationship between Aboveground Carbon Stocks and Structural Diversity in Spruce-Dominated Forest Stands in New Brunswick, Canada. Forest Science, 57(6), 506-515. https:// doi.org/10.1093/forestscience/57.6.506

Zomer, R. J., Neufeldt, H., Xu, J., Ahrends, A., Bossio, D., Trabucco, A., ... Wang, M. (2016). Global Tree Cover and Biomass Carbon on Agricultural Land: The contribution of agroforestry to global and national carbon budgets. Scientific Reports, 6(1), 29987. https://doi.org/10.1038/srep29987 